\title{
Effect of Synbiotics Supplementation in Feed on Tegal Male Duck's Internal Organs
}

\author{
Ning Iriyanti* and Bambang Hartoyo \\ Faculty of Animal Science, Jenderal Soedirman University, Purwokerto \\ *corresponding author email: ningiriyanti@gmail.com
}

\begin{abstract}
The aim of this research was to review the application of synbiotics in duck feed towards its gastrointestinal and internal organs' effectivity. The study was carried out to 60 two-months old drake. The feed given to the research subjects consisted of soybean meal, fishmeal, methionine, lysine (PT. CJeilJedang Tbk. Indonesia), corn, bran, oil, premix, $\mathrm{CaCO} 3$ and synbiotics (Lactobacillus sp. and inulin prebiotics). The ratio of feed was based on isoprotein and isocalorie, with $19 \%$ of protein and $2900 \mathrm{kcal} / \mathrm{kg}$ of metabolic energy. The research was under a fully randomized in vivo experimental method with 4 treatments and 5 replicates, using 3 drakes each. These treatments were R0: controlled feed, with $0 \%$ of synbiotics; R1: feed with $2 \%$ of synbiotics; R2: feed with $4 \%$ of synbiotics; and R3: feed with $6 \%$ of synbiotics. Data obtained were subject to analysis of variance. The results show that the use of synbiotics in feed does not have any significance on the weight and length of duodenum, jejunum, and ileum. It also does not have any significance $(P>0.05)$ on the weight and lengthof gastrointestinal and weight of gall, pancreas, gizzard, and liver. In conclusion, feed with $6 \%$ or less of synbiotics can be used without affecting the physical condition of gastrointestinal (weight and length) and internal organ (weight).
\end{abstract}

Key words: synbiotics, bowel weight, bowel length, and internal organ

Abstrak. Tujuan penelitian ini adalah mengevaluasi penggunaan sinbiotik dalam pakan terhadap kinerja saluran pencernaan dan organ-organ dalam itik jantan. Materi penelitian terdiri dari 60 ekor itik jantan, bahan pakan yang digunakan adalah : bungkil kedele, tepung ikan, metionin dan lysin (PT. Cheil Jedang Tbk Indonesia), jagung, dedak padi, minyak, premix, tepung batu kapur, dan sinbiotik (Lactobacillus sp. sebagai probiotik dan inulin sebagai prebiotik). Ransum disusun berdasarkan isoprotein dan isokalori dengan kandungan protein 19\% dan Energi Metabolik $2900 \mathrm{kkal} / \mathrm{kg}$. Penelitian dilakukan secara ekperimen in vivo dengan menggunakan Rancangan Acak Lengkap (RAL) yang terdiri dari 4 (empat) perlakuan dan 5 (lima) ulangan, masing ulangan terdiri dari 3 ekor itik jantan. Perlakuan yang dicobakan yaitu $R_{\circ}=$ Pakan Kontrol dengan $0 \%$ sinbiotik; $R_{1}=$ pakan dengan $2 \%$ sinbiotik; $R_{2}=$ pakan dengan $4 \%$ sinbiotik; $R_{3}=$ pakan dengan $6 \%$ sinbiotik. Data yang diperoleh dianalisis dengan analisis variansi. Hasil penelitian menunjukkan bahwa penggunaan sinbiotik berpengaruh tidak nyata $(P>0,05)$ terhadap bobot empedu, pancreas, gizard, hati dan jantung. Kesimpulan penelitian adalah penggunaan sibiotik sampai level $6 \%$ dalam pakan tidak mempengaruhi kondisi fisik saluran cerna dan organ-organ dalam itik.

Kata kunci: Sinbiotik, berat organ pencernaan, panjang organ pencernaan, dan organ dalam

\section{Introduction}

Duck hasa great potential to be developed as the producer of animal protein from its eggs and meat. However, the commonly used breeding method of duck is still very traditional. The feed given is still considered insufficient to fulfil the duck's need. Therefore, the productivity of duck breeding is not optimal. Mangisah et al, (2010) mention that duck farmers generally face some problems on the availability of the cheaper price, highquality feedstuffs. Farmers were forced to feed low-quality ration to the ducks that would results in lower productions as well as slower farm development.

Feed plays an important role due to its function for living, growing, production, and reproduction of ducks. Feed materials must contain sufficient and balance nutrients. Given one insufficient nutrient, disturbances may occur in the body and decrease the productivity of livestock. Improving duck productivity is by giving feed additive in form of symbiotic, the combination of a probiotic with a prebiotic given simultaneously. 
Probiotic works at its best if combined with prebiotic which is a nutrient for probiotic. Probiotic is a feed additive in form of microorganism that can live in gastrointestinal (GI) tract and in symbiosis with native microorganisms in $\mathrm{Gl}$ tract. This symbiosis is beneficial, by increasing growth and feed efficiency. It can also balance the population of microorganisms in $\mathrm{Gl}$ tract, controlpathogenic microorganisms in the host body and stimulate the immunity of the host. The main GI tract of duck is small intestine, which consists of duodenum, jejunum, and ileum, as the digesting and nutrient absorbing organ.

The ability of small intestine to digest and absorb nutrients is affected by surface area of epithelium, the number of mucosal folds and the number of villi and microvilli that expand the absorption area (Austic and Nesheim, 1990). It is also affected by the height and surface area of villi, duodenum, jejunum, and ileum (Sugito, et al, 2007).

Mechanism of action of prebiotics and probiotics in improving the durability of intestineSynbiotic can improvefeed efficiency by suppressing competition between host and microorganisms in intestine. Probiotics, as live microorganisms or spores, can live and thrive in intestine. They can give benefits to their host, directly or through their metabolites, so that beneficial microorganisms are well developed. Probiotics, on the other hand, are undigested feed materials that can stimulate growth and activity numbers of selected microorganism in GI tract and can improve the host wellbeing. Prebiotics also known as adequate nutrition for beneficial microorganisms.

Besides GI tract, the productivity of duck is also affected by the condition of its internal organs. Pancreas, gall, gizzard and liver are the most vital internal organs of duck contributing to its gastrointestinal activity. The main function of pancreas is to produce lipolytic, amylolytic and proteolytic enzymes. These enzymes will convert macro nutrient into micro nutrient so it is readily absorbed. Gall will produce bile salts which can help in reinforcing digesting and absorbing processes. Gizzard will greatly assist the digesting process mechanically. Metabolism process of nutrients is taking places in liver which processed nutrients are readily to be circulated throughout the body. The aim of this research was to review the application of synbiotics in duck feed towards its gastrointestinal and internal organs' effectivity

\section{Materials and Methods}

This research was conducted to sixty 4month-old Tegal drakes weighed 600-800 gram for 2 months. Feed composition consisted of corn, bran, soybean meal, fishmeal, oil, $\mathrm{CaCO}_{3}$, topmix, lysine, methionine, and synbiotics. The composistion ratio of feed was based on isocalorie and isoprotein, with $19 \%$ of protein and $2900 \mathrm{kcal} / \mathrm{kg}$ of metabolic energy.

\section{The production of synbiotics inoculum (Crueger and Crueger, 1990)}

The isolate of indigenous probiotic microorganism Lactobacillus $s p$. was cultivated in de Man Rogosa Sharp Broth (MRSB) liquid media with the addition of mineral 1 ( $0.6 \mathrm{~g}$ of $\mathrm{K}_{2} \mathrm{HP}_{4}$ in $100 \mathrm{ml}$ aquadest) and mineral $2(1.2 \mathrm{~g}$ of $\mathrm{NaCl} ; 1.2 \mathrm{~g}$ of $\left(\mathrm{NH}_{4}\right)_{2} \mathrm{SO}_{4} ; 0.6 \mathrm{~g}$ of $\mathrm{KH}_{2} \mathrm{PO}_{4}$; $0.12 \mathrm{~g}$ of $\mathrm{CaCl}_{2} ; 0.25 \mathrm{~g}$ of $\mathrm{MgSO}_{4} .7 \mathrm{H}_{2} \mathrm{O}$ in $100 \mathrm{ml}$ aquadest). It was incubated using batch culture for $2 \times 24$ hours or until it achieved $10^{9} \mathrm{cell} / \mathrm{ml}$ microbial content.

\section{The production of synbiotics starter (Iriyanti dan Rimbawanto, 2001)}

a. $100 \mathrm{~g}$ of smooth bran was added in aquadest with ratio of $1: 0.5$. This substrate was mixed with mineral $1\left(0.6 \mathrm{~g}\right.$ of $\mathrm{K}_{2} \mathrm{HP}_{4}$ in $100 \mathrm{ml}$ aquadest) and mineral $2(1.2 \mathrm{~g}$ of $\mathrm{NaCl} ; 1.2 \mathrm{~g}$ of $\left(\mathrm{NH}_{4}\right)_{2} \mathrm{SO}_{4} ; 0.6 \mathrm{~g}$ of $\mathrm{KH}_{2} \mathrm{PO}_{4}$; $0.12 \mathrm{~g}$ of $\mathrm{CaCl}_{2} ; 0.25 \mathrm{~g}$ of $\mathrm{MgSO}_{4} .7 \mathrm{H}_{2} \mathrm{O}$ in $100 \mathrm{ml}$ aquadest). 
b. $4 \%$ of Inulin prebiotic was added, then it was sterilized using autoclave in $121^{\circ} \mathrm{C}$ for 20 minutes

c. This substrate was inoculated using $10 \%$ $(\mathrm{v} / \mathrm{w})$ inoculum with $10^{9} \mathrm{cell} / \mathrm{ml}$ microbial content.

d. It was fermented using batch culture in a room temperature and using $\mathrm{pH} 6.8$ for $5 \times 24$ hours.

e. The substrate mixture was dried in $40^{\circ} \mathrm{C}$ for $2 \times 24$ to activate probiotic microorganisms. It was mashed before it was ready to use as a feed mixture.

The research was conducted in Seloarum farm, Sokaraja, Banyumas and Nutrition Laboratory, Faculty of Animal Science, University of Jenderal Soedirman. The experimental design used was a fully randomized with 4 treatments and 5 replications. Data were analyzed using analysis of variance (Steel and Torrie, 1994). The treatments were tested, namely: RO: controlled feed, with $0 \%$ of synbiotics; R1: feed with $2 \%$ of synbiotics; R2: feed with $4 \%$ of synbiotics; and R3: feed with $6 \%$ of synbiotics. Variables measured in this research were the weight and length of intestine (duodenum, jejunum, and ileum), as well as the weight of internal organs (pancreas, gall, gizzard and liver).

\section{Results and Discussion}

The result of synbiotics in feed of Tegal drakes on the weight of duodenum, jejunum, and ileum is presented in Table 1.
Table 1 shows the approximatemean weight of duodenum, jejunum and ileum is $23.44 \pm 2.96$; $6.15 \pm 1.39$ and $7.16 \pm 1.38$ grams, respectively, lower than $66.0 \pm 2.00,14.1 \pm 5.00$ and $14.7 \pm 7.00$ grams, respectively (Sumiati, 2003) on kayambang (Salivinia molesta) addition in drake feed. Zainal (2007) on silage in feed of drake reported duodenum, jejenum and ileum approximate weight was $32.6 \pm 0.41,8.26 \pm 0.63$ and $7.01 \pm 0.56$ grams, respectively. Rukmiasih (2002) reported $34.00 \pm 3.00$ grams duodenum weights and $12.8 \pm 2.00$ grams jejenum + ileum on high fiber and vitamin $\mathrm{E}$ supplementation in feed of Mandalung ducks.

Analysis of variance result showed that the use of synbiotics in feed was not significant $(P>$ 0.05 ) on the intestine weight of Tegal drake because synbiotics was not working perfectly and therefore, the bacteria attached to the intestinal villi were insufficient. Fuller (1989) stated that the response of probiotic organisms has not showed its usefulness, because the ability of probiotics to stick to the epithelial tissue of intestinal wall, the specificity of host and the ability of probiotics to grow in the intestinal environment are still lacking. To survive in the Gl tract environment, probiotics should be able to attach to and proliferate on the surface of the GI tract (Jin et al, 1997).

Another contributing factor to synbiotics was the nutrient content of feed, mainly fiber. Feed ratio in this research contained the same fiber composition. Therefore, the weight of intestine was also relatively the same.

Table 1. The mean weight of duodenum, ileum, and jejunum in Tegal drakes (male ducks)

\begin{tabular}{cccc}
\hline \multirow{2}{*}{ Treatments } & \multicolumn{3}{c}{ weight (gram) $^{\text {Dud }}$} \\
\cline { 2 - 4 } & Duodenum $^{\text {ns }}$ & Jejunum $^{\text {ns }}$ & lleum $^{\text {ns }}$ \\
\hline 0\% Synbiotics & $23.62 \pm 3.24$ & $5.36 \pm 1.06$ & $7.58 \pm 2.09$ \\
$2 \%$ Synbiotics & $23.38 \pm 2.63$ & $6.40 \pm 1.42$ & $7.38 \pm 1.26$ \\
$4 \%$ Synbiotics & $21.16 \pm 4.05$ & $6.88 \pm 1.67$ & $6.08 \pm 0.91$ \\
$6 \%$ Synbiotics & $25.58 \pm 1.91$ & $5.96 \pm 1.42$ & $7.60 \pm 1.27$ \\
\hline Mean & $23.44 \pm 2.96$ & $6.15 \pm 1.39$ & $7.16 \pm 1.38$ \\
\hline
\end{tabular}

ns=non significant 
Feed with high crude fiber content affects the condition of $\mathrm{Gl}$ tract, i.e. increasing the weight and length of intestine (Iyayi, 2005). The LAB will produce organic acids that prevent colonization of pathogenic bacteria in the small intestine and pathogenic bacteria be issued with feces.

According to Langhout (2000), organic acids may reduce the production of toxins by bacteria and change the morphology of the intestinal wall. Organic acids can also reduce the colonization of pathogenic bacteria; however, this will not lead to an increased weight of small intestine.

According to Metchnikoff in 1998 in Sultan et al (2006) stated that Lactobacillus is one kind of bacteria that are beneficial to intestinal microflora of livestock. The mechanism of action of Lactobacillus is by helping the digestion of proteins, carbohydrates and dietary fat and the absorption of other important elements such as minerals, amino acids and vitamins.

The result of synbiotics use in feed of drakes originating from Tegal on the length of duodenum, jejunum, and ileum can be seen in Table 2.

Table 2 shows the approximate mean length of duodenum, jejunum and ileum was $86.23 \pm 14.18,29.55 \pm 6.91$ and $35.45 \pm 10.93 \mathrm{~cm}$, respectively, shorter than $34.00 \pm 3.85$, $92.30 \pm 11.47$ and $89.90 \pm 10.50 \mathrm{~cm}$, respectively, of 7-week-old drakes hybrid line SM3 (Wasilewski, 2014). While in 7-week-old drakes hybrid line AF51 was $32.40 \pm 3.57$, $94.80 \pm 2.94$ and $91.60 \pm 2.54 \mathrm{~cm}$, respectively.

According to Rodríguez-Lecompte et al (2010), the addition of prebiotics in chicken feed may increase the number of microorganisms in Gl tract and stimulate the growth of digesting organ to reach its optimal function. Widyastuti dan Soarianawati (1999) stated that probiotics can prevent the growth of organism that are disadvantageous to the host. It can improve digestibility and absorption of nutrients by stimulating peristalsis movement, a bowel movement due to the competition between probiotic microorganisms with pathogenic bacteria to attach to the intestinal epithelium that will simultaneously help the activity and intestinal development.The higher the level of probiotics used in feed, the slower the rate of digestion and nutrient absorption will be. To maximize the absorption of these nutrients, the absorption area needs to be expanded.

Analysis of variance result showed that the use of synbiotics in feed was not significant $(P>$ $0.05)$ to intestine length of Tegal drake because fibers and fats in feed were given at the same amount. The length of duodenum is affected by fat as well as fiber in feed consumed by broiler chicken because duodenum is also the site of lipolysis in chicken. The level of crude fiber in the diet greatly affect the performance and growth of livestock. Crude fiber is needed to stimulate the movement of livestock digestive

Table 2. The mean length of duodenum, ileum, and jejunum in Tegal drakes (male ducks)

\begin{tabular}{cccc}
\hline \multirow{2}{*}{ Treatments } & \multicolumn{3}{c}{ length $(\mathrm{cm})$} \\
\cline { 2 - 4 } & Duodenum $^{\text {ns }}$ & Jejunum $^{\text {ns }}$ & lleum $^{\text {ns }}$ \\
\hline 0\% Synbiotics & $90.00 \pm 14.34$ & $25.40 \pm 4.04$ & $34.70 \pm 5.74$ \\
2\% Synbiotics & $79.60 \pm 24.52$ & $31.30 \pm 6.83$ & $45.60 \pm 28.52$ \\
$4 \%$ Synbiotics & $80.20 \pm 14.45$ & $34.00 \pm 9.14$ & $29.60 \pm 4.16$ \\
6\% Synbiotics & $95.10 \pm 3.44$ & $27.50 \pm 7.63$ & $31.90 \pm 5.30$ \\
\hline Mean & $86.23 \pm 14.18$ & $29.55 \pm 6.91$ & $35.45 \pm 10.93$ \\
\hline
\end{tabular}

ns=non significant 
tract. In ruminants, crude fiber is used as an energy source. However, its function is limited in poultry. Lack of fiber in poultry feed can cause indigestion, but an excessive amount of crude fiber can also lower the digestibility of feed.

High fiber content in feed will decrease the rate of digestion due to the need of intensive digestion. The slow pace of digestion may allow the enzyme to hydrolyze nutrients longer, so the absorption of nutrients will be more effective and the digestibility of feed will increase. Increased digestibility is likely due to the increased capacity of the digestive organs (Ade, 2002). Amrullah (2004) stated that fiberenriched diet will change the size of the digestive tract into heavier, longer, and thicker. Poultry, especially chicken, has a poor ability to utilize crude fiber. However, crud fiber is still needed in small quantities, because it can affect the histology of the digestive tract.

The result of synbiotics use in feed of drakes originating from Tegal on the percentage of internal organs is presented in Table 3. Table 3 shows the approximate mean percentage of gall is $0,25 \pm 0,08(\%)$, pancreas $0,32 \pm 0,02(\%)$,

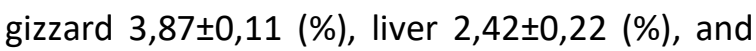
heart 0,82 $\pm 0,03(\%)$.

$\mathrm{R}_{2} \quad(4 \%)$ showed the highest mean percentage of gall, $0.31 \%$, while the lowest was $\mathrm{R}_{0}(0 \%), 0.19 \%$. Analysis of variance result showed that synbiotics in feed was not significant ( $P>0.05$ ) on mean weight of gall. Gall acts as a conduit of bile from liver to the

Table 3. The mean percentage of internal organs of Tegal drakes (male ducks)

\begin{tabular}{ccccc}
\hline \multirow{2}{*}{ Treatments } & \multicolumn{4}{c}{ Percentage of internal organ (\%) } \\
\cline { 2 - 5 } & Gall $^{\text {ns }}$ & Pancreas $^{\text {ns }}$ & Gizzard $^{\text {ns }}$ & Liver $^{\text {ns }}$ \\
\hline 0\% Synbiotics & $0.19 \pm 0.10$ & $0.31 \pm 0.09$ & $3.71 \pm 0.20$ & $2.74 \pm 0.72$ \\
2\% Synbiotics & $0.23 \pm 0.04$ & $0.34 \pm 0.05$ & $3.78 \pm 0.17$ & $2.08 \pm 0.31$ \\
4\% Synbiotics & $0.31 \pm 0.22$ & $0.36 \pm 0.08$ & $3.95 \pm 0.39$ & $2.40 \pm 0.33$ \\
6\% Synbiotics & $0.28 \pm 0.12$ & $0.28 \pm 0.06$ & $4.05 \pm 0.16$ & $2.44 \pm 0.25$ \\
\hline Mean & $0.25 \pm 0.08$ & $0.32 \pm 0.02$ & $3.87 \pm 0.11$ & $2.42 \pm 0.22$ \\
\hline
\end{tabular}

ns=non significant intestine with the bile duct enlarged to form gallbladder (Amrullah, 2004). Gall is located in gallbladder which consists of two channels that transfer bile from the liver to the small intestine (North and Bell, 1990).

Bile salts in gall will interact with fat to form micelles. Micelles will dissolve fat and provide a transport mechanism of fat from the lumen into the mucosal cells of small intestine (Guyton and Hall, 2000). Such mechanism fragments fat into smaller units by the agitation of small intestine. Emulsification and fat hydrolysis involving pancreatic lipase produced monoglycerides, fatty acids, glycerol, and a small portion of diglycerides and triglycerides (Ganong, 1995). Bile works to secrete cholesterol and to form an emulsion of fat with the help of bile acids secreted by liver. It consists of three channels (ducts); ductushepatocystici that connects the gallbladder to liver, ductushepatoentericus that carry bile to the duodenum and ductuscysticocutericus which is the channel between gallbladder and duodenum (Ressang, 1984).

$\mathrm{R}_{2}(4 \%)$ had the highest mean percentage of pancreas, $0.36 \%$, while the lowest mean percentage of gall was $R_{3}(6 \%)$ or $0,28 \%$. Analysis of variance result showed that the use of synbiotics in feed was not significant $(P>0.05)$ on the mean weight of pancreas. Pancreas is one of complementary digestive organs (North and Bell, 1990). Therefore, the addition of synbiotics is not significantly affecting pancreas. 
Pancreas produces lipolytic, amylolytic, and proteolytic enzymes. The increased weight of pancreas isone of adaptation forms to provide enough digestive enzymes. Pancreas is located in the middle rounds of the U-shaped duodenum and responsible for the secretion of digestive enzymes (exocrine) and hormone secretion (endocrine). Pancreas secretes amylase, trypsin, lipase enzymes to aid the digestion of carbohydrates, protein and fat. The increased weight of pancreas is one form of adaptation to meet the increasing needs of digestive enzymes. One of the functions of the pancreas is to produce lipolytic, amylolytic and proteolytic enzymes. Pancreas is one organ that has an important role in food digestion. Pancreas produces fluid that is channeled into the duodenum at the pylorus valve place (Purwanti et al, 2015)

$R_{2} \quad(4 \%)$ also showed the highest mean percentage of gizzard which is $4,05 \%$, whereas the lowest mean percentage of gizzard was $R_{3}$ (6\%) which is $3.71 \%$. These results were higher compared to previous studies from Putnam (1991), gizzard weights ranged from $1.6 \%-2.3 \%$, and Dwipayanti (2008), ranged from 0.13\%$0.15 \%$. Analysis of variance result showed that the use of synbiotics in feed was not significant $(P>0.05)$ to mean weight of gizzard.

Gizzard is a simple organ where digestion and storage of food is taking places. It consists of strong muscle fibers. Gizzard in poultry has the same function as teeth in mammals, which is to reduce the size of food particles mechanically. Gizzard muscle contraction will happen if food was present. The mechanical digestion of food occurs in gizzard known as the mastication process. Gizzard located between proventriculus and the upper limit of small intestine. The greater the food particles, the faster the contraction of muscles will be and the food particles will be longer in the gizzard. The size of gizzard is variable, depending on the type of food (Ade, 2002).
Ro (0\%) showed the highest mean percentage of liver, $2.74 \%$, while the lowest mean percentage of gizzard was $\mathrm{R}_{3}(6 \%), 2.08 \%$, higher than $1.70 \%-2.80 \%$ (Putnam, 1991) and $1.42 \%-1.60 \%$ (Dwipayanti, 2008). Analysis of variance result showed that the use of synbiotics in feed was not significant $(P>0.05)$ on mean weight of liver.

Liver is a reddish brown organ, consists of two large lobes and is located in the arch of the duodenum and gizzard. Liver has a complex functionin the metabolism of carbohydrates, fats, protein, iron. In addition, liver also plays a crucial role in the secretion of bile, detoxification, red blood cell formation, and metabolism and absorption of vitamins (Ressang, 1984). The weight of liver will increase with age. Size, weight, consistency, and color of liver depends on the race, age and nutritional status of individual animals (Nickel et al, 1997). In addition, liver color depends on the status of poultry nutrition. Normal liver is a reddish brown or light brown. However, when a high-fat diet was conducted, the color will be yellow (McLelland, 1990).

\section{Conclusions}

Synbiotics does not have any significant impact on the physical condition of gastrointestinal (weight and length) and internal organ (weight). Synbiotics can be used as a mix in feed of Tegal drake within $2 \%-6 \%$ range.

\section{References}

Ade, A. 2002. Carcass weight percentage and internal organ of Broiler Chicken Fed with taro leaf powder (Coiocasia esculenta L.) in ration. Undergraduate thesis. Faculty of Animal Science, Bogor Agriculture Institute. Bogor.

Amrullah, IK. 2004. Broiler Nutrition. Self-Farming series. Lembaga Satu Gunung Budi, Bogor.

Anggorodi. 1995. General Feedstuff Study. Gramedia Pustaka Utama. Jakarta. 
Austic, RE. and Nesheim. 1990. Poultry Production, 13th ed. Lea and Febiger. Philadelph. London. p.29-30.

Crueger, W. and A Crueger. 1990. Biotechnology: A Textbook of Industrial Microbiology. Editor Thomas D Brock. Sinauer Associates, Sunderland, MA

Dwipayanti, Y. 2008. Internal organ profile and hispathology of intestine and liver of local chicken infected with Ascaridiagalli treated with jatropha leaf powder (Jathropacurcas L.). Undergraduate thesis. Department of Animal Nutrition and Feedstuff. Faculty of Animal Science. Bogor Agriculture Institute.

Fuller, R. 1989. Probioticln Man and Animal. Journal Appl. Bacterial. Hal 365-378.

Ganong, WF. 1995. Textbook of Medical Physiology.Translated by Petrus, Penerbit Kedokteran EGC, Jakarta.

Guyton, AC. dan Hall. 2000. Textbook of Medical Physiology. Ed ke-9. Translated by Irawati Setiawan. EGC, Jakarta.

Iriyanti, N. dan EA Rimbawanto. 2001. Probiotic inoculation of Lactobacillus $s p$. Derived from local chicken to improve layer performance. Research report. Faculty of Animal Science UNSOED.

Iyayi, 2005. Effect of three sources of fibre and period of feeding on the performance, carcass measures, organs relative weight and meat quality in broilers. International Journal Poultry Science 4:695-700.

Jin, JZ, YW Ho, N Abdullah and S Jalaludin. 1997. Probiotic in Poultry: Modes of Action. Journal of World Poultry Science. Hal 351-368.

Langhout,P. 2000. New Additives for broiler chicken. Feed Mix. The International Journal on feed, Nutrition and Technology 9(6):24-27.

Mangisah, I, HI Wahyuni, Tristiarti, S Sumarsih and S Setyaningrum. 2010. Nutritive Value of Fermented Water Hyacinth (Eichornia crassipes). Leaf with Aspergillus niger in Tegal Duck. Journal of Animal Productio. 12 (2):100-104. May,2010.

Mclelland, J. 1990. A Colour Atlas of Avian Anatomy. Walfe Publishing Ltd., London, England.

Nickel, RA, A Schummer, E Seiferie, WG Siller and RAL Wight. 1997. Anatomy of The Domestic Birds. Verlap Paul Parey, Berlin.

North, MO dan DD Bell. 1990. Commercial Chicken Production Manual. $4^{\text {th }}$ Edition. An Avi Book, Van Nostrand Reinhold, New York.

Piliang, WG dan S Djojosoebagio. 1990. Metabolism of Fat, Protein and Crude Fiber. Nutrition Physiology I. Bogor Agriculture Institute Press. Bogor.Putnam, PA. 1991. Hand Book of Animal
Science. Academic Press, San Diego.Purwanti, S Zuprizal, T Yuwanta and Supadmo. 2015. Phytobiotic Utilization as Feed Additive in Feed for Pancreatic Enzyme Activity of Broiler Chicken. Journal of Animal Production. 17(3):154-160.

Ressang, AA. 1984. Pathology for Veterinarian. Edisi kedua. NV Percetakan Bali,Denpasar.

Rodríguez-Lecompte JC, Brady J, Camelo-Jaimes G, Sharif S, Crow G, Ramirez-Yanez G, Guenter W and House JD. 2010. Intestinal characterization of avian defensins and cytokines after the early administration of probiotic with organic acids in broilers. Avian Immunology Research Group. Budapest, Hungary

Rukmiasih, Harapin, Hafidh H, Harry T, Uhi SY. 2002. High fiber feed and vitamin E supplement on the performance of Mandalung duck. Laboratory of beef cattle nutrition Faculty of Animal Science. Bogor Agriculture Institute.

Steel, RGD and Torrie. 1994. Principle and Procedures of Statistics: Second Ed. McGraw-Hill Book Company

Sugito, W Manalu, Astuti DA, Handharyani E. dan Chairul. 2007. Intestine morphometric and performance of Broiler chicken fed under heat stressand n-hexane extract of 'jaloh' bark peel (Salix tetraspermaRozb). Media Peternakan 30:198-206.

Sultan A, Durrani FR, Suhail SM, Ismail M, Durrani Z and Naila Chand. 2006. Comparative effects of yogurt as probiotic on the performance of broiler chicks. Pakistan J BiolSci 9:88-92.

Sumiati, 2003. Percentage of digestive tract weigh and internal organ of male local duck (Anasplatyrhyncos) fed on varied level of kayambang (Salvinamotesta) in feed. Department of Nutrition and Animal Feed. Faculty of Animal Science. Bogor Agriculture Institute.

Wasilewski, R Dariusz Kokoszyński, Anna Mieczkowska. 2014. Structure of the digestive system of ducks depending on sex and genetic background. 1UTP University of Science and Technology, Faculty of Animal Breeding and Biology, Department of Poultry Breeding and Animal Products Evaluation, Bydgoszcz, Poland.

Widyastuti, Y dan E Soarianawati. 1999. Character of lactic acid bacteria ka Enterococcus sp. Isolated from cattle digestive tract. Journal of mikrobiologi Indonesia.4(2): 50-53.

Zainal, Y. 2007. Effect of compete silage ration on internal organ of male Mojosari alabio duck. Undergraduate thesis. Department of Nutrition and Animal Feed. Faculty of Animal Science. Bogor Agriculture Institute. 